\title{
PENGARUH EFFLUENT SAPI TERHADAP BEBERAPA SIFAT FISIK DAN KIMIA TANAH PADA LAHAN ULTISOL DI PT GREAT GIANT PINEAPPLE LAMPUNG TENGAH
}

\author{
Jamal Hamdan Sanjaya, Afandi, Nur Afni Afrianti \& Hery Novpriansyah \\ Jurusan Agroteknologi, Fakultas Pertanian Universitas Lampung \\ Jl. Prof. Dr. Soemantri Brodjonegoro, No.1 Bandar Lampung 35145 \\ E-mail: jamalhsanjaya@gmail.com
}

\begin{abstract}
ABSTRAK
Effluent sapi adalah pupuk organik tanah yang berasal dari limbah cair campuran kotoran sapi padat, urin, air dan sisa kandang lainnya. Kandungan unsur kimia yang terdapat pada effluent sapi diharapkan dapat memperbaiki sifat fisik dan kimia tanah. Penelitian ini bertujuan untuk mengetahui pengaruh pemberian effluent sapi terhadap beberapa sifat fisik dan kimia tanah pada ultisol di PT Great Giant Pineapple. Hipotesis yang diajukan yaitu pemberian effluent sapi memberikan pengaruh positif dan semakin tinggi taraf perlakuan yang diberikan semakin besar pengaruhnya dalam memperbaiki sifat fisik dan kimia tanah. Penelitian dilaksanakan pada bulan September hingga bukan November 2014 pada lahan Ultisol di PT Great Giant Pineapple lokasi 90A. Penelitian ini menggunakan Rancangan Acak Lengkap dengan faktor perlakuan penelitian yaitu effluent sapi dengan taraf perlakuan $0 \mathrm{lha}^{-1}, 200.000 \mathrm{hha}^{-1}, 300.000 \mathrm{lha}^{-1}$, dan $450.000 \mathrm{lha}^{-1}$. Variabel pengamatan sifat fisik meliputi stabilitas agregat tanah dan kekuatan tanah, sedangkan sifat kimia meliputi $\mathrm{pH}$ tanah $\mathrm{H}_{2} \mathrm{O}, \mathrm{C}-$ Organik, N-Total serta Nisbah C/N. Data yang diperoleh dari hasil analisis laboratorium kemudian dianalisis menggunakan Analisis Ragam dan dilanjutkan dengan Uji BNT pada taraf $=0,05$. Data tersebut kemudian juga diharkatkan berdasarkan kriteria tertentu. Hasil penelitian menunjukkan bahwa aplikasi effluent sapi berpengaruh positif dalam memperbaiki stabilitas agregat tanah dan $\mathrm{pH}$ tanah, namun tidak berpengaruh terhadap C-Organik, N-Total, maupun nisbah $\mathrm{C} / \mathrm{N}$ tanah. Aplikasi effluent sapi sampai dengan taraf 450.0001 ha $^{-1}$ masih cukup rendah dan belum efisien untuk meningkatkan C-Organik, N-Total, maupun nisbah C/N tanah.
\end{abstract}

Kata kunci: effluent sapi, sifat fisik tanah, sifat kimia tanah, Ultisol.

\section{PENDAHULUAN}

Nanas merupakan salah satu komoditas ekspor dari sektor perkebunan hortikutura. Di Indonesia produksi nanas setiap tahun mengalami peningkatan seiring peningkatan permintaan di pasar dunia. Salah satu perusahan perkebunan yang membudidayakan tanaman nanas adalah PT Great Giant Pineapple (GGP) yang berlokasi di Provinsi Lampung. PT Great Giant Pineapple berdiri sejak tahun 1979. Saat itu lahan yang dipergunakan 10.000 ha, hingga saat ini berkembang menjadi 30.000 ha diolah dan ditanam sebagian besar dengan tanaman nanas.

Sejak tahun 1979 hingga 2015 ( \pm 30 tahun), tanah di perkebunan nanas PT GGP telah diolah dan dimanfaatkan secara intensif. Hal ini menyebabkan tanah di perkebunan tersebut mengalami degradasi, sehingga terjadi penurunan kualitas tanah baik pada sifat fisik, kimia, dan biologi tanah. Menurut Banuwa (2013), lahan terdegradasi didefinisikan sebagai lahan dengan produktivitas rendah atau tidak produktif untuk pertanian.
Degradasi tanah menyiratkan penurunan produktivitas tanah dan kemampuan lahan. Menurut Foth (1989), degradasi lahan berkaitan dengan penurunan kualitas sifat fisik, kimia dan biologi tanah. Tanah dengan drainase buruk, mengalami kompaksi tanah, pencucian unsur hara, $\mathrm{pH}$ masam, defisiensi bahan organik, dan erosi dapat mempengaruhi pertumbuhan dan perkembangan tanaman serta produksi tanaman nanas. Saat ini permasalahan degradasi pada lahan perkebunan PT GGP harus ditangani dengan serius, karena telah berimbas terhadap produksi, kualitas tanaman, dan buah nanas. Berbagai upaya telah dilakukan oleh PT GGP untuk memperbaiki kualitas tanah akibat penggunaan secara intensif selama ini, baik secara kimia, fisik maupun biologi.

Pengelolaan kesuburan tanah merupakan salah satu faktor yang mempengaruhi persiapan kondisi lahan bagi tanaman. Untuk itu diperlukan sistem pengelolaan kesuburan tanah yang baik agar dapat menjaga produktivitas tanah secara berkelanjutan, mampu mendukung pertumbuhan tanaman secara optimal, dan 
dapat meningkatkan produktivitas tanaman itu sendiri. Pengolahan tanah merupakan kegiatan yang paling pertama dilakukan. Adanya degradasi lahan menyebabkan perlu adanya strategi untuk memperbaiki keadaan tanah. Salah satunya adalah pemanfaatan effluent sapi yang merupakan bahan organik dan diaplikasikan pada kegiatan pengolahan tanah.

Effluent sapi adalah pupuk organik tanah yang berasal dari limbah cair campuran kotoran sapi padat, urin, air dan sisa kandang lainnya. Cairan tersebut didominasi oleh urin, berwarna kuning kecoklatan. Dalam proses pembuatan effluent sapi melalui separator, kotoran sapi dipisahkan menjadi dua yaitu cairan (effluent) dan padatan (solid manure).

Effluent sapi untuk kegiatan budidaya nanas PT GGP berasal dari PT Great Giant Livestock (GGL). PT GGLC adalah salah satu perusahaan yang bergerak di bidang penggemukan sapi dengan kapasitas mencapai 30.000 ekor yang menghasilkan limbah padat dan cair dalam jumlah yang besar yang sangat potensial digunakan dalam bidang pertanian. Effluent sapi sebagai bahan organik memiliki peran sebagai bahan perekat antar partikel tanah untuk dapat meningkatkan aerasi tanah, memperbaiki aerasi dan perkolasi serta membuat struktur tanah menjadi remah dan mudah diolah (Subowo dkk., 1990).

PT Great Giant Pineapple (PT GGP) mulai membuat kebijakan baru pada tahun 2013, yaitu dengan mengaplikasikan effluent sapi pada lahan sebelum tanam dengan tujuan untuk memperbaiki sifat fisik dan kimia tanah perkebunan nanas yang diusahakan.

\section{BAHAN DAN METODE}

Penelitian ini telah dilaksanakan di lokasi 90A, lahan perkebunan nanas di PT Great Giant Pineapple, Terbanggi Besar, Lampung Tengah, Provinsi Lampung. Analisis sifat fisik dan kimia tanah dilaksanakan di Laboratorium Ilmu Tanah, Fakultas Pertanian, Universitas Lampung. Penelitian ini dilaksanakan mulai bulan September hingga bulan November 2014.

Alat yang digunakan dalam penelitian ini secara umum meliputi peralatan lapang dan peralatan laboratorium. Peralatan lapang digunakan untuk mengambil sampel tanah dan peralatan laboratorium adalah peralatan yang mendukung untuk analisis dari masing-masing perlakuan yang ditetapkan. Bahan yang digunakan dalam penelitian ini adalah tanah yang diaplikasi effluent pada lahan perkebunan nanas lokasi 90A di PT Great Giant Livestock, zat kimia untuk analisis, aquades, label dan plastik. Penelitian ini merupakan percobaan lapangan yang dilaksanakan di lokasi 90A, lahan perkebunan nanas PT GGP dengan luas lahan penelitiannya adalah $3.600 \mathrm{~m}^{2}$. Rancangan penelitian yang digunakan adalah Rancangan Acak Lengkap dengan faktor perlakuan penelitian ini adalah dosis aplikasi effulent sapi dengan empat (4) taraf perlakuan, yaitu $0 \mathrm{lha}^{-1}, 200.000 \mathrm{lha}^{-1}, 300.000 \mathrm{lha}^{-1}$, dan 450.000 lha $^{-1}$. Masing-masing taraf perlakuan (aplikasi dosis effluent sapi) diterapkan pada lahan yang berukuran $18 \mathrm{~m}$ x $50 \mathrm{~m}$ dan pengambilan sampel yang dianalisis diambil sebanyak 3 ulangan. Penentuan titik pengambilan sampel tanah dilakukan dengan metode diagonal pada kedalaman 0-20 cm.

Adapun variabel yang diamati adalah: Stabilitas Agregat Tanah (Metode Ayakan Kering-Basah), Kekuatan Tanah (Penetrometer), $\mathrm{pH} \mathrm{H}_{2} \mathrm{O}$ (pH meter), C-Organik Tanah (Metode Walkey and Black), N-Total Tanah (Metode Kjedahl), Nisbah C/N. Data yang diperoleh dari hasil analisis laboratorium kemudian dianalisis menggunakan Analisis Ragam dan dilanjutkan dengan Uji BNT pada taraf $=0,05$. Data hasil analisis kimia tanah kemudian diharkatkan menggunakan kriteria dari Balai Penelitian Tanah (2005), data hasil analisis effluent sapi menggunakan kriteria dari Permentan No 70/Permentan/S.R.140/10/2011 dan data hasil analisis stabilitas agregat tanah menggunakan kriteria dari Afandi (2005), sedangkan kekuatan tanah menggunakan kriteria dari Gugino dkk (2009).

\section{HASIL DAN PEMBAHASAN}

Hasil analisis stabilitas agregat tanah yang dilakukan di laboratorium disajikan pada Tabel 1. Berdasarkan uji analisis varian (ANOVA) menunjukkan bahwa pemberian effluent kotoran sapi berpengaruh nyata terhadap kestabilan agregat tanah. Rata-rata diperoleh nilai stabilitas agregat tanah berkisar antara 77,78 - 143,33. Dari hasil analisis (Tabel 1) menunjukkan bahwa semakin tinggi taraf effluent yang diberikan ke tanah penelitian menyebabkan kemantapan agregat tanah semakin menurun. Hal ini terlihat dari nilai ratarata stabilitas agregat setelah diaplikasi effluent sapi secara berurutan dari nilai tertinggi hingga ke rendah adalah taraf effluent $0 \mathrm{lha}^{-1}$ sebesar 143,33 (sangat mantap), taraf $200.000 \mathrm{lha}^{-1}$ sebesar 99,86 (sangat mantap), taraf effluent $300.000 \mathrm{lha}^{-1}$ sebesar 79,78 (mantap), dan yang terendah adalah taraf effluent 450.000 lha $^{-1}$ sebesar 77,78 (mantap).

Hasil analisis kekuatan tanah yang dilakukan di lapangan setelah dilakukan analisis, rata-rata berkisar 98,36 - 102,67 psi. Dengan rincian terendah pada taraf pemberian effluent $300.000 \mathrm{lha}^{-1}$ sebesar 98,36 psi, kemudian diikuti taraf pemberian effluent $450.000 \mathrm{lha}^{-1}$ 
sebesar 101,01 psi, taraf pemberian effluent $0 \mathrm{lha}^{-1}$ sebesar 101,33 psi, dan taraf pemberian effluent 200.000 1 ha ${ }^{-1}$ sebesar 102,67 psi. Nilai rata-rata kekuatan tanah dijelaskan pada Tabel 2.

Berdasarkan Permentan No 70/Permentan/ S.R.140/10/2011 mengenai persyaratan teknis minimal pupuk cair organik menunjukkan bahwa effluent sapi (Tabel 3) yang digunakan dalam penelitian ini memiliki kandungan C-organik, N-Total, $\mathrm{P}, \mathrm{K}, \mathrm{Zn}, \mathrm{Mn}$ dan $\mathrm{Cu}$ termasuk dalam kriteria rendah (tidak memenuhi syarat minimal pupuk organik cair), sedangkan Fe memenuhi syarat minimal pupuk organik cair. Hasil analisis $\mathrm{pH}$ tanah yang dilakukan di laboratorium disajikan pada Tabel 4. Dari Tabel 4 rata-rata diperoleh nilai $\mathrm{pH}$ tanah $\mathrm{H}_{2} \mathrm{O}$ berkisar antara 4,28 - 4,38. Hasil analisis ragam menunjukkan bahwa pemberian effluent sapi berpengaruh nyata terhadap terhadap $\mathrm{pH}_{2} \mathrm{O}$, dimana
$\mathrm{pH}$ tanah tertinggi adalah pada taraf $300.000 \mathrm{lha}^{-1}$ dan terendah pada taraf $200.000 \mathrm{lha}^{-1}$. Hasil analisis Corganik tanah yang dilakukan di Laboratorium disajikan pada Tabel 5. Dari Tabel 5 rata-rata C-Organik tanah berkisar 1,22-1,5\% dan termasuk pada harkat rendah. Nilai rata-rata C-Organik tanah tertinggi diperoleh pada taraf $300.000 \mathrm{lha}^{-1}$ sebesar $1,5 \%$ dan terendah pada taraf $0 \mathrm{lha}^{-1}$ sebesar 1,22\%. Berdasarkan analisis ragam menunjukkan bahwa pemberian effluent kotoran sapi tidak berpengaruh nyata terhadap C-organik tanah.

Hasil analisis N-Total Tanah yang telah dilakukan disajikan pada Tabel 6. Dari tabel 6 rata-rata diperoleh nilai N-Total Tanah berkisar antara 0,11-0,6\%. Hasil Analisis pengaruh effluent kotoran sapi terhadap kadar $\mathrm{N}$ total tanah menunjukkan bahwa nilai N-Total Tanah tertinggi adalah pada perlakuan pemberian effluent $450.000 \mathrm{lha}^{-1}$ sebesar $0,6 \%$ (tinggi) dan terendah pada

Tabel 1. Pengaruh effluent kotoran sapi terhadap stabilitas agregat tanah

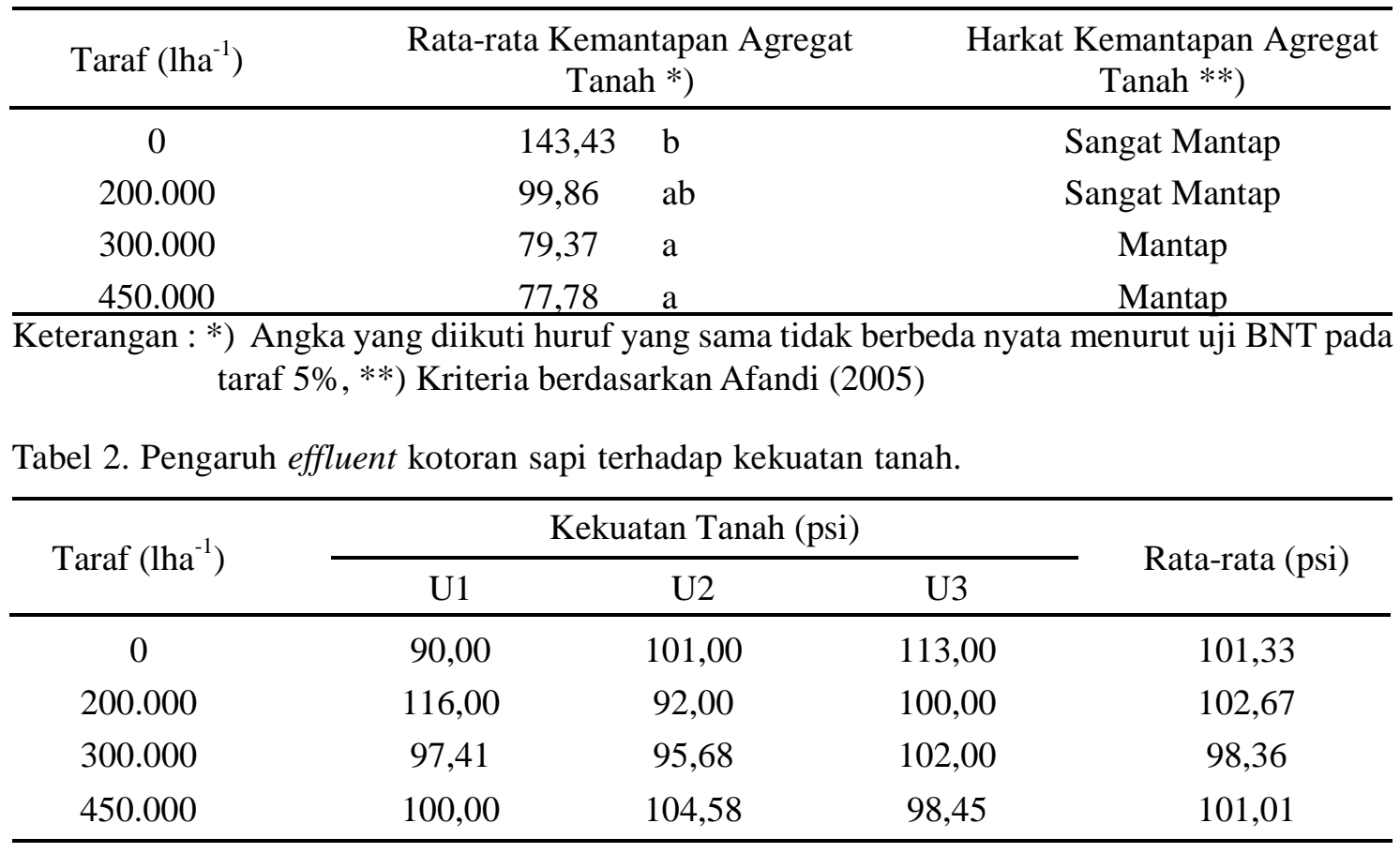

Tabel 3. Hasil analisa kandungan kimia effluent sapi

\begin{tabular}{cccc}
\hline Unsur kimia & Kandungan & Unsur kimia & Kandungan \\
\hline C-organik $(\%)$ & 2,92 & $\mathrm{Na}(\mathrm{ppm})$ & 1274,83 \\
N-total $(\%)$ & 1,06 & $\mathrm{Fe}(\mathrm{ppm})$ & 454,00 \\
$\mathrm{P}(\mathrm{ppm})$ & 129,18 & $\mathrm{Zn}(\mathrm{ppm})$ & 39,17 \\
$\mathrm{~K}(\mathrm{ppm})$ & 761,18 & $\mathrm{Mn}(\mathrm{ppm})$ & 19,85 \\
$\mathrm{Ca}(\mathrm{ppm})$ & 379,00 & $\mathrm{Cu}(\mathrm{ppm})$ & 2,28 \\
$\mathrm{Mg}(\mathrm{ppm})$ & 103,72 & $\mathrm{~S}(\mathrm{ppm})$ & 7339,83 \\
\hline
\end{tabular}

Sumber: Compost Plant Soil Sustainability Department PT. GGP 
taraf $200.000 \mathrm{lha}^{-1}$ sebesar $0,11 \%$ (rendah). Secara umum pengaruh effluent kotoran sapi terhadap kadar $\mathrm{N}$ total tanah menunjukkan bahwa semakin tinggi pemberian effluent maka semakin meningkat kadar $\mathrm{N}$ total tanah. Namun berdasarkan analisis ragam menunjukkan bahwa pemberian effluent kotoran sapi tidak berpengaruh nyata terhadap $\mathrm{N}$-total tanah. Berdasarkan hasil pengukuran C-Organik dan N-Total maka didapatkan nisbah $\mathrm{C} / \mathrm{N}$ yang berkisar antara 8,37 13,28. Rata-rata nilai nisbah C/N dijelaskan pada Tabel 7. Hasil analisis pengaruh effluent kotoran sapi terhadap nisbah $\mathrm{C} / \mathrm{N}$ menunjukkan bahwa nilai nisbah $\mathrm{C} / \mathrm{N}$ tertinggi adalah pada taraf perlakuan $200.000 \mathrm{lha}^{-1}$ sebesar 13,28 (sedang) dan terendah pada taraf perlakuan $450.000 \mathrm{lha}^{-1}$ (rendah). Berdasarkan analisis ragam menunjukkan bahwa pemberian effluent kotoran sapi tidak berpengaruh nyata terhadap $\mathrm{C} / \mathrm{N}$ rasio. Nisbah $\mathrm{C} / \mathrm{N}$ tertinggi adalah pada perlakuan pemberian effluent pada taraf $200.000 \mathrm{lha}^{-1}$ dan terendah pada taraf 450.000 lha ${ }^{-1}$. Nisbah $\mathrm{C} / \mathrm{N}$ tanah menunjukkan tingkat laju dekomposisi bahan organik tanah. Semakin rendah nilai nisbah $\mathrm{C} / \mathrm{N}$ tanah maka semakin mudah dan cepat mengalami dekomposisi. Effluent merupakan pupuk cair yang dihasilkan dari pemisahan kotoran sapi yaitu berupa liquid manure (effluent), sedangkan solid manure dijadikan bahan untuk pembuatan kompos. Hasil

Tabel 4. Pengaruh effluent kotoran sapi terhadap $\mathrm{pH} \mathrm{H}_{2} \mathrm{O}$

\begin{tabular}{cccccc}
\hline \multirow{2}{*}{ Taraf $\left(\mathrm{lha}^{-1}\right)$} & \multicolumn{3}{c}{$\mathrm{pH}\left(\mathrm{H}_{2} \mathrm{O}\right)$} & \multirow{2}{*}{ Rata-Rata*$)$} & Kriteria**) \\
\cline { 2 - 4 } & $\mathrm{U} 1$ & $\mathrm{U} 2$ & $\mathrm{U} 3$ & & \\
\hline 0 & 4,33 & 4,3 & 4,34 & $4,32 \mathrm{~b}$ & Sangat Masam \\
200.000 & 4,28 & 4,28 & 4,28 & $4,28 \mathrm{c}$ & Sangat Masam \\
300.000 & 4,37 & 4,37 & 4,4 & $4,38 \mathrm{a}$ & Sangat Masam \\
450.000 & 4,31 & 4,34 & 4,32 & $4,32 \mathrm{~b}$ & Sangat Masam \\
\hline
\end{tabular}

Keterangan : *) Angka yang diikuti huruf yang sama tidak berbeda nyata menurut uji BNT pada taraf 5\%.**) Kriteria berdasarkan Balai Penelitian Tanah (2005)

Tabel 5. Pengaruh effluent kotoran sapi terhadap C-Organik tanah

\begin{tabular}{|c|c|c|c|c|c|}
\hline \multirow{2}{*}{ Taraf $\left(\mathrm{lha}^{-1}\right)$} & \multicolumn{3}{|c|}{ C-Organik (\%) } & \multirow{2}{*}{$\begin{array}{c}\text { Rata-Rata } *) \\
(\%)\end{array}$} & \multirow{2}{*}{ Kriteria**) } \\
\hline & $\mathrm{U} 1$ & $\mathrm{U} 2$ & $\mathrm{U} 3$ & & \\
\hline 0 & 1,11 & 1,25 & 1,29 & $1,22^{\mathrm{tn}}$ & Rendah \\
\hline 200.000 & 1,78 & 1,43 & 1,26 & $1,49^{\mathrm{tn}}$ & Rendah \\
\hline 300.000 & 1,48 & 1,53 & 1,47 & $1,50^{\mathrm{tn}}$ & Rendah \\
\hline 450.000 & 1,57 & 1,19 & 1,42 & $1,39^{\mathrm{tn}}$ & Rendah \\
\hline
\end{tabular}

Keterangan :*) Angka yang diikuti huruf yang sama tidak berbeda nyata menurut uji BNT pada taraf 5\%.**) Kriteria berdasarkan Balai Penelitian Tanah (2005)

Tabel 6. Pengaruh effluent kotoran sapi terhadap N-Total tanah

\begin{tabular}{ccccccc}
\hline \multirow{2}{*}{ Taraf $\left(\mathrm{lha}^{-1}\right)$} & \multicolumn{3}{c}{ N-Total (\%) } & Rata-Rata (\%) & Kriteria* \\
\cline { 2 - 4 } & $\mathrm{U} 1$ & $\mathrm{U} 2$ & $\mathrm{U} 3$ & & \\
\hline 0 & 0,1 & 0,12 & 0,13 & $0,12^{\text {tn }}$ & Rendah \\
200.000 & 0,12 & 0,13 & 0,09 & $0,11^{\text {tn }}$ & Rendah \\
300.000 & 0,13 & 0,09 & 1,19 & $0,47^{\text {tn }}$ & Sedang \\
450.000 & 1,56 & 0,12 & 0,1 & $0,6^{\text {tn }}$ & Tinggi \\
\hline
\end{tabular}

Keterangan : *) Angka yang diikuti huruf yang sama tidak berbeda nyata menurut uji BNT pada taraf 5\%. **) Kriteria berdasarkan Balai Penelitian Tanah (2005) 
Tabel 7. Pengaruh effluent kotoran sapi terhadap Nisbah C/N tanah

\begin{tabular}{ccccccc}
\hline \multirow{2}{*}{ Taraf $\left(\right.$ lha $\left.^{-1}\right)$} & \multicolumn{3}{c}{ Nisbah C/N } & Rata-Rata (\%) & Kriteria* \\
\cline { 2 - 4 } & $\mathrm{U} 1$ & $\mathrm{U} 2$ & $\mathrm{U} 3$ & & \\
\hline 0 & 11,10 & 10,42 & 9,92 & $10,48^{\text {tn }}$ & Rendah \\
200.000 & 14,83 & 11,00 & 14,00 & $13,28^{\text {tn }}$ & Sedang \\
300.000 & 11,38 & 17,00 & 1,24 & $9,87^{\text {tn }}$ & Rendah \\
450.000 & 1,01 & 9,92 & 14,20 & $8,37^{\text {tn }}$ & Rendah \\
\hline
\end{tabular}

Keterangan : *) Angka yang diikuti huruf yang sama tidak berbeda nyata menurut uji BNT pada taraf 5\%.**) Kriteria berdasarkan Balai Penelitian Tanah (2005)

pengamatan (Tabel 1) menunjukkan bahwa perbedaan perlakuan pengaplikasian effluent sapi pada tanah Ultisol memberikan pengaruh nyata terhadap stabilitas agregat tanah, yaitu semakin tinggi dosis aplikasi effluent yang diberikan ke tanah menyebabkan tingkat kemantapan agregat tanah semakin menurun, sehingga dapat menurunkan nilai kepejalan pada tanah.

Stabilitas agregat tanah merupakan indikator kualitas tanah yang baik karena sangat sensitif terhadap perubahan yang disebabkan pengolahan tanah dan sistem pertanaman (Islam dan Weil, 2000). Semakin tinggi stabilitas agregat tanah membuat struktur tanah lebih kuat dalam menahan proses penghancuran. Tanahtanah yang memiliki struktur yang mantap tidak mudah hancur oleh pukulan-pukulan air hujan sehingga akan tahan terhadap erosi. Sebaliknya struktur tanah yang tidak mantap sangat mudah hancur oleh pukulan air hujan menjadi butiran-butiran halus sehingga menutupi pori-pori tanah dan menyebabkan infiltrasi terhambat karena adanya pemadatan pada tanah. Peningkatan ukuran dan stabilitas agregat akan berpengaruh positif terhadap sifat fisik tanah lainnya, diantaranya meningkatkan kapasitas retensi air dan jumlah air tersedia, pori makro dan meso, porositas total, aerasi tanah serta permeabilitas tanah maupun infiltrasi serta dapat menurunkan kepekaan tanah terhadap erosi (Kurnia, 1996).

Hasil pengamatan (Tabel 2) menunjukkan bahwa berdasarkan kriteria kekuatan tanah yang dikemukakan oleh Gugino, dkk. (2009), kekuatan tanah pada semua taraf pemberian effluent termasuk dalam zona hijau (< 200 psi) yang berarti bahwa tanah tersebut memiliki nilai kekuatan tanah yang baik untuk pertumbuhan akar tanaman. Kekuatan tanah terbaik didapatkan pada perlakuan pemberian effluent $300.000 \mathrm{lha}^{-1}$. Semakin rendah nilai kekuatan tanah yang didapat, maka semakin baik untuk pertumbuhan akar tanaman, yang artinya akar tanaman mampu tumbuh dan berkembang dengan baik dalam tanah tersebut.
Menurut Sarkar dkk (2003), penambahan bahan organik dapat meningkatkan karbon, stabilitas agregat, dan laju infiltrasi permukaan tanah sekaligus mengurangi pemadatan tanah. Berdasarkan analisis varian menunjukkan bahwa nilai kekuatan tanah pada semua sampel perlakuan tidak berbeda nyata ( $<200 \mathrm{psi})$, artinya nilai kekuatan tanah baik pada perlakuan tanpa pemberian effluent (kontrol) maupun dengan pemberian effluent sampai taraf $450.000 \mathrm{lha}^{-1}$ adalah sama, sehingga pemberian effluent kotoran sapi ke dalam tanah sampai taraf $450.000 \mathrm{lha}^{-1}$ belum efektif terhadap kekuatan tanah.

Berdasarkan hasil analisis Laboratorium menunjukkan bahwa effluent sapi (Tabel 3) yang digunakan dalam penelitian ini memiliki kandungan Corganik, N-Total, P, K, Zn, Mn dan Cu termasuk dalam kriteria rendah (tidak memenuhi syarat minimal pupuk organik cair), sedangkan Fe memenuhi syarat minimal pupuk organik cair. Sehingga untuk pemanfaatan effluent sapi sebagai pupuk organik ini akan dibutuhkan dalam jumlah yang banyak agar mampu memperbaiki sifat-sifat tanah. Hal ini didukung dengan hasil analisis statistik yang menunjukkan bahwa pemberian effluent kotoran sapi sampai dengan taraf $450.000 \mathrm{lha}^{-1}$ tidak berpengaruh nyata terhadap kandungan $\mathrm{C}$-organik, $\mathrm{N}$ total, maupun nisbah $\mathrm{C} / \mathrm{N}$ tanah (Tabel 5, Tabel 6 dan Tabel 7). Sehingga dapat disimpulkan bahwa dosis aplikasi effluent kotoran sapi sampai dengan taraf 450.000 lha $^{-1}$ masih cukup rendah atau belum efisien untuk meningkatkan $\mathrm{C}$-organik, $\mathrm{N}$-total, maupun nisbah $\mathrm{C} / \mathrm{N}$ tanah.

Selain dikarenakan dosis aplikasi effluent yang masih cukup rendah, kemungkinan lain yang dapat menyebabkan perlakuan pemberian effluent belum efisien untuk memperbaiki sifat-sifat tanah tersebut adalah kemungkinan terjadi kehilangan (loss) sebagian dari effluent kotoran sapi saat pengaplikasian. Seperti yang dikemukakan oleh Sentana (2010) bahwa effluent kotoran sapi mudah mengalami pencucian (leaching) 
ataupun terevaporasi. Hal ini didukung dengan iklim Indonesia yang merupakan salah satu negara beriklim tropika basah dengan curah hujan rata-rata tahunan tinggi yang berkisar $2.500 \mathrm{~mm}-3.000 \mathrm{~mm}$, dengan suhu udara rata-rata di siang hari mencapai $32^{\circ} \mathrm{C}$ serta intensitas radiasi matahari yang tinggi menyebabkan tingginya laju penguapan (evaporasi) dan dekomposisi bahan organik pada wilayah ini (Ferraris, 1992 dan Rahmat, $d k k$., 2014). Curah hujan yang tinggi akan menyebabkan sebagian dari effluent kotoran sapi hilang akibat terbawa aliran air gravitasi, dan suhu udara serta intensitas radiasi matahari yang tinggi akan menyebabkan sebagian dari effluent kotoran sapi hilang akibat proses penguapan maupun proses dekomposisi, dan hal ini juga menyebabkan penurunan jumlah effluent kotoran sapi yang masuk ke dalam tanah yang merupakan sumber bahan organik tanah.

\section{KESIMPULAN}

Dari hasil penelitian yang dilakukan dapat disimpulkan bahwa: Aplikasi effluent sapi berpengaruh positif dalam memperbaiki stabilitas agregat tanah dan $\mathrm{pH}$ tanah, namun tidak berpengaruh terhadap kandungan C-Organik, N-Total, maupun nisbah C/N tanah. Aplikasi effluent sapi sampai dengan taraf $450.000 \mathrm{lha}^{-1}$ masih cukup rendah dan belum efisien untuk meningkatkan C-Organik, N-Total, maupun nisbah C/N tanah.

\section{DAFTAR PUSTAKA}

Afandi. 2005. Penuntun Praktikum Fisika Tanah. Universitas Lampung. Bandar Lampung.

Banuwa, I.S. 2013. Erosi. Kencana Perdana Media Group. Jakarta.

Balittan, 2005. Petunjuk Teknis Analisis Kimia Tanah, Tanaman, Air, dan Pupuk. Badan Penelitian dan Pengembangan Pertanian Departemen Pertanian.
Ferraris, R. 1992. Seedbed factor affecting establishment of summer crops in a Vertisol. Journal of Soil Science and Tillage Research 23: 1-2.

Foth, H.D. 1989. Fundamentals of Soil Science. John Wiley \& Sons. New York.

Gugino, B.K., O.J. Idowu, R.R. Schindelbeck, H.M. Van Es., D.W. Wolfe., B.N. Moebius-Clune, J.E. Thies, dan G.S. Abawi. 2009. Cornell Soil Health Assessment Training Manual. 2nd Ed. Cornell University, Geneva. New York.

Islam, K. R, and R. R. Weil. 2000. Soil quality indicator properties in Mid-Atlantic soils ar influenced by conservation management. J.Soil and water Corns. 55: 69-78.

Kurnia, U. 1996. Kajian Metode Rehabilitasi Lahan untuk Meningkatkan dan Melestarikan Produktivitas Tanah. Disertasi. Institut Pertanian Bogor. Bogor.

Rahmat, A., Afandi, T.K.B. Manik, dan P. Cahyono. 2014. Pengaruh irigasi dan mulsa organik terhadap pertumbuhan tanaman nanas (Ananas comosus) di daerah tropika basah. J. Agrotek Tropika 2(1): 155-158.

Sarkar, S., S.R. Singh, dan R.P. Singh. 2003. The effect of organic and inorganic fertilizers on soil physical condition and the productivity of a rice-lentil cropping sequence in India. Journal of Agricultural Science. 3(140): 419- 425.

Sentana, S. 2010. Pupuk Organik, Peluang dan kendalanya. Prosiding Seminar Nasional Teknik Kimia "kejuangan". Pengembangan Teknologi Kimia untuk Pengolahan Sumberdaya Alam Indonesia. Yogyakarta, 26 januari 2010.

Subowo, J. Subaga, dan M. Sudjadi. 1990. Pengaruh bahan organik terhadap pencucian hara tanah Ultisol Rangkasbitung, Jawa Barat. Pemberitaan Penelitian Tanah dan Pupuk. 9: 26-31. 